\title{
Microbial biomass in a haplic gleysol in the Mato Grosso State Pantanal
}

\author{
Daniela Tiago da Silva Campos, Maíra de Emílio Martins, \\ Indira Ashant Martins Messias, Patrícia Teles Medeiros
}

Federal University of Mato Grosso, Cuiabá, MT, Brazil. *Corresponding author, e-mail: camposdts@yahoo.com.br

\begin{abstract}
The Pantanal is a biome that lives under water conditions and resists to two very distinct periods: flooded and drained. The objective of this study was to evaluate the behavior and quantify the microbial biomass during the flood period, in soils under riparian forest and cerrado vegetation in Mato Grosso State pantanal, at two depths. At depths of 0.00-0.05 m, the highest levels of C-BM and RB were found in cerrado soils; for the metabolic quotient no differences were observed in the two vegetations; the total organic carbon content was higher in riparian forest soils and the microbial quotient was higher in cerrado soils. Bacteria and fungi were found to be more abundant in the cerrado soil at the two evaluated depths and the actinomycetes in the forest. It is concluded that in the flood period there are the presence of active microorganisms which produce a differentiated biomass due to the phytophysiognomy of the location.
\end{abstract}

Keywords: Biomass carbon, basal respiration, bacteria, fungi and actinomycetes

\section{Introduction}

Flooded areas, which are extensive and heterogeneous, such as those of the Pantanal region, play an important role in biological diversity, due to the diversity of natural habitats that open up opportunities for feeding and reproductive niches, as well as essential functions in the ecosystem such as the carbon stock, fish production and recharge of aquifers (Alho, 2008).

The low slope in the Pantanal region makes it difficult to drain the water and, in combination with the meso relief, is possible to observe differents and characteristic environments, associated with the mosaic vegetation, such as the "mountain ranges", with denser tree vegetation, or riparian vegetation, which is very dynamic, due to the sinuous and unstable fluvial beds (Pott \& Pott, 2005).

The seasonal changes between flood and drought phases and also the permanente cover vegetation results in the addition of large amounts of nutrients and their rapid cycling, allowing productivity for a region considered to be poor and directly affecting the local microbial community (Alho, 2008).

The microbial population in the soils represents the most abundant and diversified life form in the planet and plays important roles in the decomposition of vegetal residues, mineralization, biological fixation of nitrogen, formation of 
mycorrhizal associations and in bioremediation, besides others (Bunemann et al. , 2006).

The aim of this study was to evaluate the behavior and quantify the microbial biomass of the soils under riparian forest (RF) and cerrado in the Poconé, MT, Pantanal reigion.

\section{Material and Methods}

The study was conducted with soils collected in the Private Reserve of Natural Heritage (RPPN) / National System of Conservation Units (SNUC), from the Pantanal Social Service of Commerce (SESC), located in the Poconé municipality, in the northeast region of Pantanal, Mato Grosso State, Braizil, at 16 $6^{\circ} 33^{\prime} 19^{\prime \prime}$ south latitude and $56^{\circ} 17^{\prime} 11$ "west longitude coordinates, with $120 \mathrm{~m}$ of altitude. The Reserve occupies an area of approximately $1,076 \mathrm{~km}^{2}$.

The soil is classified as haplic gleysol (Embrapa, 1999). The climate of the region is AW, with average annual temperature between $22^{\circ} \mathrm{C}$ and $32^{\circ} \mathrm{C}$ and annual mean rainfall between 1100 and $1200 \mathrm{~mm}$ (Hasenack et al., 2003).

The collection was realized in May 2010, corresponding to the ebb period, which is from April to June, in which the region has the water level reduced until reaching total drought, a period known as the dry period of the
Pantanal region. In the month of collection the precipitation was $200 \mathrm{~mm}$ and the temperature varied between $23^{\circ} \mathrm{C}$ to $28^{\circ} \mathrm{C}$.

The soil was collected in two phytophysiognomies: riparian forest and cerrado, at depths of 0.00-0.05 $\mathrm{m}$ and 0.05-0.20 m. In each phytophysiognomy, a transect was performed, where 20 sub-samples (10 for each depth) were collected at points located $30 \mathrm{~cm}$ from each other, making a total of 40 samples.

In the riparian forest, the soil presented a clayey texture (630 $\mathrm{g}$ clay $\mathrm{kg}$ dry soil-1) and vegetation composed of thinner trees closer to each other and near the river bed; The cerrado had shruby vegetation, with the presence of grasses and soil with loamy sand texture (134 g of clay kg dry soil-1).

The samples were conditioned in plastic bags, protected from light and kept in thermal boxes until the arrival in the laboratory. Samples were dried in the air to adjust the humidity to 50 to $60 \%$ of the field capacity, sifted through a sieve of $2 \mathrm{~mm}$ mesh, packed in plastic bags and kept in a cold room at $4^{\circ} \mathrm{C}$. The chemical characterization of soils was performed in a private laboratory, following a methodology recommended by Embrapa (1997) and shown in Table 1.

Table 1. Chemical characteristics of soils under riparian forest and cerrado in the Pantanal of the Mato Grosso State.

\begin{tabular}{|c|c|c|c|c|c|c|c|c|c|}
\hline \multirow{2}{*}{ Areas } & Depth & $\mathrm{pH}$ & $\mathbf{P}$ & K & $\mathrm{Ca}$ & $\mathrm{Mg}$ & Al & $\mathrm{H}+\mathrm{Al}$ & \multirow{2}{*}{$\frac{\text { MO }}{\mathrm{g} \mathrm{dm}^{-3}}$} \\
\hline & $\mathrm{m}$ & water & \multicolumn{2}{|c|}{$--m g d^{-3}-$} & \multicolumn{4}{|c|}{ 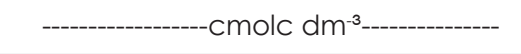 } & \\
\hline \multirow[t]{2}{*}{ Forest } & $0,00-0,05$ & 5,4 & 38 & 135 & 4,3 & 2,0 & 0,3 & 11,2 & 67,0 \\
\hline & $0,05-0,20$ & 4,5 & 4,3 & 103 & 1,1 & 1,3 & 3,1 & 8,8 & 48,4 \\
\hline \multirow[t]{2}{*}{ Cerrado } & $0,00-0,05$ & 4,8 & 4,6 & 44 & 0,6 & 0,3 & 0,6 & 4,9 & 22,7 \\
\hline & $0,05-0,20$ & 4,6 & 3,0 & 32 & 0,1 & 0,1 & 0,8 & 2,9 & 10,7 \\
\hline
\end{tabular}

The microbial biomass carbon (C-BM), along with basal respiration (RB) were quantified by the fumigation-incubation method (Alef, 1995), in which were determined the C-BM and $\mathrm{CO}_{2}$ from $50 \mathrm{~g}$ of soil. The C-BM was obtained from the calculation: biomass- $\mathrm{C}=$ (fumigated $\mathrm{CO}_{2}-\mathrm{C}-\mathrm{CO}_{2}-\mathrm{C}$ not fumigated) / $\mathrm{kc}$; where kc corresponds to a coefficient which varies according to the incubation temperature. The $\mathrm{Kc}$ of 0.45 was used, which corresponds to an incubation temperature of $25^{\circ} \mathrm{C}$.

The metabolic quotient $\left(\mathrm{qCO}_{2}\right)$ was

obtained by the ratio between RB and C-BM (Anderson \& Domsch, 1993); the microbial quotient (qMic) was obtained by the C-BM/TOC ratio (Sparling, 1992). Total organic carbon was determined by the equipment TOC Multi N/C 3100 HT 1300-Analytik Jena AG.

For the enumeration of viable total microorganisms, the serial dilution technique described in Wollum (1982) using the following culture media was used: nutrient agar for total bacteria, potato dextrose water (PDW) medium for total fungi and soil extract for actinomycetes. 
The plates were incubated at $28^{\circ} \mathrm{C}$, the bacteria reading was performed after 24 hours, for fungi in 72 hours and for actinomycetes in 7 days.

The data were submitted to the nonparametric Kruskal-Wallis multiple comparisons test, since the experiment consists of areas with distant treatments, with no randomization. The statistical package Assistat, version 7.6, beta 2012 was used for calculations (Silva \& Azevedo, 2002).

\section{Results and Discussion}

It was verified the presence of total microorganisms in activity in Pantanal soils, which was proved by the statistical differences observed in the two evaluated areas. The behavior of the microbial biomass of the soils was different in the two areas evaluated for most of the quantified microbiological parameters. The levels of C-BM, RB and qMic were higher in soils under the cerrado vegetation, at both depths. For the metabolic quotient $\left(\mathrm{qCO}_{2}\right)$ no significant statistical differences were observed (Table 2).
Souza et. al (2008) studying the cerrado soil also did not observed variations in the $\mathrm{qCO}_{2}$ between the different grazing intensities evaluated. According to these authors, very high values of $\mathrm{qCO}_{2}$ are found in stressful environmental conditions, in which BMS spends more $C$ for its maintenance and as BMS becomes more efficient, less $\mathrm{C}$ is lost as $\mathrm{CO}_{2}$ by respiration and a significant fraction is incorporated into the microbial tissue; Therefore, soils with low $\mathrm{qCO}_{2}$ would be closer to the equilibrium stage.

The metabolic quotient $\left(\mathrm{qCO}_{2}\right)$, the basal respiration rate of the microbial biomass and the attributes related to the organic carbon cycle were evaluated in the study of Cardoso et al. (2009), which verified that although there was a tendency for greater release of $\mathrm{C}-\mathrm{CO}_{2}$ in environments under greater anthropic intervention, as in cultivated pastures implanted instead of native forests, significant increases were observed.

Table 2. Microbial biomass carbon (C-BM), basal respiration (BR), metabolic quotient $\left(\mathrm{aCO}_{2}\right)$, total organic carbon (TOC) and microbial quotient (qMic) in soils under riparian forest and cerrado in the Pantanal of the Mato Grosso do State, Brazil.

\begin{tabular}{|c|c|c|c|c|c|c|}
\hline Areas & $\begin{array}{l}\text { C-BM } \\
--\mathrm{C}-\mathrm{CO}_{2} \mu \\
\end{array}$ & $\begin{array}{r}\text { RB } \\
\text { ug of } \mathrm{CO}_{2} \mathrm{~g}^{-1}-- \\
\end{array}$ & & $\begin{array}{c}\mathrm{qCO}_{2} \\
\mu \mathrm{g} \mathrm{C}-\mathrm{CO}_{2} \mu \mathrm{g} \text { de } \mathrm{C}-\mathrm{BM} \text { day }{ }^{-1}\end{array}$ & $\begin{array}{l}\text { TOC } \\
\text { g. } \mathrm{kg}^{-1}\end{array}$ & $\begin{array}{c}\text { QMic } \\
\%\end{array}$ \\
\hline & \multicolumn{6}{|c|}{ - } \\
\hline Forest & 29.75 & 14.31 & $\mathrm{~b}$ & $0.51 \mathrm{a}$ & $8.43 \mathrm{a}$ & 3.52 \\
\hline Cerrado & 150.35 & 49.69 & a & 0.38 a & $1.74 \mathrm{~b}$ & 86.4 \\
\hline \multirow[t]{2}{*}{$\mathrm{CV}(\%)$} & 22 & 26 & & 26 & 32 & 32 \\
\hline & \multicolumn{5}{|c|}{$0,05-0,20 \mathrm{~m}$} & \\
\hline Forest & $19.74 \quad \mathrm{~B}$ & 4.17 & $a$ & $0.24 \quad a$ & $2.68 \mathrm{a}$ & 7.36 \\
\hline Cerrado & 138.86 & 8.04 & $a$ & $0.07 \mathrm{a}$ & $0.07 \mathrm{~b}$ & 1983.71 \\
\hline CV $(\%)$ & 20 & 22 & & 25 & 22 & 36 \\
\hline
\end{tabular}

Means followed by the same letter in column and for each variable are not different, according to Tukey's test at $5 \%$ ( $p>0.05)$.

The released $\mathrm{CO}_{2}$ is generated entirely

by $\mathrm{C}-\mathrm{BM}$ mineralization in response to the rapid increase in soil water potential and that the flooded and drained periods releases the physically protected organic matter, increasing the amount of $C$ extractable from organic matter by up to $200 \%$ (Fierer \& Schimel, 2003).

The soil of the forest presented higher total organic carbon (TOC) when compared to the cerrado, which confirms the organic matter content, which was $67 \mathrm{~g} \mathrm{dm}^{-3}$ in the forest and $22.7 \mathrm{~g} \mathrm{dm}^{-3}$ for cerrado. The decomposition of organic matter in soils under anoxic conditions, such as those of Pantanal, is low and carbon tends to accumulate in the soil (Alho et al., 2008).
Habitats change as water moves nutrients and sediments, depositing inorganic and organic materials, which enrich micro-habitats, favoring the proliferation of micro-organisms, as well as invertebrates and fish.

The microbiological attributes are higher in soils of the South-Mato Grosso Pantanal that passed through the conversion of the native forest into cultivated pasture and of native pastures to continuous grazing system (Cardoso et al., 2009). It was verified that despite the cerrado soil presented lower content of organic matter and TOC, the microorganisms were able to mineralize $\mathrm{C}-\mathrm{BM}$, releasing more $\mathrm{CO}_{2}$, showing greater efficiency in the organic matter $\mathrm{C}$ extraction. 
The number of colony forming units (CFU) of bacteria and total fungi was higher in cerrado soils and in the depth of 0.00-0.05 m. For the other evaluated microorganisms and depth, no significant statistical differences were observed (Table 3).
In the forest were found lower amounts of microorganisms, but the highest organic matter and total organic carbon content in the two depths. The deposition and decomposition of organic residues in forest soils is linked to the growth and development of the microorganisms

Table 3. Number of colony forming units for total bacteria in nutrient agar medium (Agar), total fungi in PDA medium and actinomycetes in soil extract medium (Soil ext), in soil samples collected under forest and cerrado in the Mato Grosso State Pantanal.

\begin{tabular}{|c|c|c|c|c|c|c|c|}
\hline & Agar & PDA & Soil ext & Agar & PDA & Soil e & ext \\
\hline Areas & \multicolumn{3}{|c|}{ № UFCx $10^{3} \mathrm{~g}^{-1}$ dry soil } & \multicolumn{4}{|c|}{$N^{\circ}$ UFCX $10^{3} \mathrm{~g}^{-1}$ dry soil } \\
\hline & \multicolumn{3}{|c|}{$0.00-0.05 \mathrm{~m}$} & \multicolumn{4}{|c|}{$0,05-0,20 \mathrm{~m}$} \\
\hline Forest & 125.33 & 13.67 & $26.0 \mathrm{a}$ & 13,67 & 5,33 & 14,33 & $a$ \\
\hline Cerrado & 258.33 & 26.67 & $12.0 \mathrm{a}$ & 26,67 & 2,33 & 9,66 & \\
\hline $\mathrm{CV}(\%)$ & 5.13 & 9.35 & 7.09 & 2.57 & 4.07 & 20.5 & 52 \\
\hline
\end{tabular}

that are responsible for the activity, but was not observed in this study, which indicates that the microorganisms present in the forest were not in large number, but were able to degrade the plant materials available to them during the soil collection period (Perez et al., 2004).

The number of actinomycetes found in the higher amonuts in forest soils may have been due to the fact that they present a great diversity of habitats and also because they produce spores that can increase their survival in unfavorable environments.

In soils, actinomycetes are numerically less dominant than other bacterial populations, but are more numerous when compared to fungal populations (Wollum, 1982).

The activity of soil microorganisms is considered a positive attribute for soil quality, with basal respiration being a sensitive indicator of the residues decomposition, the soil organic carbon and ecosystem disturbances. It is important to careful interpretate the results, since the high values of basal respiration do not always indicate desirable conditions, where a high respiration rate can mean, in the short term, release of nutrients to the plants and, in the long term, loss of carbon from the soil to the atmosphere (Tótola \& Chaer, 2002).

These results are different from Melloni et al. (2001) and Stieven et al. (2009), who verified an increase in soil microbial population in a forest ecosystem with lower water content and report that this result is due to the greater cycling of organic matter or to the presence of organic residues with higher $\mathrm{C} / \mathrm{N}$ ratio in these environments.

\section{Conclusion}

In soils of the Mato Grosso State Pantanal, in the period of ebb, there are the presence of aerobic microorganisms and that are able to survive in the region's flood period.

The vegetation under the soils of the Pantanal biome modifies the amount and activity of the soil microorganisms.

\section{References}

Alef, K. Estimation of the hydrolysis of fluorescein diacetate. 1995. In: Alef, K., Nannipieri, P. (Eds.), Methods in Applied Soil Microbiology and Biochemistry. Academic Press: London, P.232238.

Alho, C.J.R. 2008. Biodiversity of the Pantanal: response to seasonal flooding regime and to environmental degradation. Brazilian Journal Biology 68, 957-966. http://www.scielo.br/pdf/ $\mathrm{bjb} / \mathrm{v} 68 \mathrm{n} 4 \mathrm{~s} 0 / \mathrm{a05v684s.pdf}$

Anderson, J.P., Domsch, K.H. 1993. The metabolic quotient for $\mathrm{CO}_{2}\left(\mathrm{qCO}_{2}\right)$ as a specific activity parameter to asses the effects of environmental conditions, such as $\mathrm{pH}$, on the microbial biomass of forest soils. Soil Biology and Biochemistry 25 (3), 393-395. http://www.sciencedirect.com/ science/article/pii/0038071793901407

Bunemann, E.K., Scwenke, G.D., Van Zwieten, L. 2006. Impact of agricultural inputs on soil organisms - a review. Australian Journal Soil Research 44, 379-406. http://www.publish.csiro. au/index.cfm 
Cardoso, E. L., Silva, M.L.N., Moreira, F. M. S., Curi, N. 2009. Atributos biológicos indicadores da qualidade do solo em pastagem cultivada e nativa no Pantanal. Pesquisa Agropecuária Brasileira 44, 631-637. http://WwW.scielo.br/scielo. php? script=sci_nlinks\&ref $=000087 \&$ pid $=\$ 0100$ 204X201100100002100005\&lng=en

Empresa Brasileira de Pesquisa Agropecuária. 1999. Centro Nacional de Pesquisa de Solos (Rio de Janeiro, RJ). Sistema brasileiro de classificação de solos. Brasília: SPI/Embrapa CNPS. 412p.

Empresa Brasileira de Pesquisa Agropecuária. 1997. Centro Nacional de Pesquisa de Solos. Manual de métodos de análise de solo. 2. ed. Rio de Janeiro. 212p.

Fierer, N., Schimel, J.P. 2003. A proposed mechanism for the pulse in carbon dioxide production commonly observed following the rapid rewetting of a dry soil. Soil Science Society of America Journal 67, 798-805. https://www. agronomy.org/publications/sssaj/pdfs/67/3/798

Hasenack, H., Cordeiro, J.L.P., Hofmann, G.S. 2003. O clima da RPPN SESC-Pantanal. Porto Alegre: UFRGS. $27 \mathrm{p}$.

Melloni, R., Pereira, E.G., Trannin, I.C.B., Santos, D.R., Moreira, F.M.S., Siqueira, J.O. 2001. Características biológicas de solos sob mata ciliar e campo Cerrado no Sul de Minas Gerais. Ciência Agrotécnica 25 (1), 7-13. http://Www.scielo.br/scielo. php?script=sci_nlinks\&ref $=000102 \&$ pid $=$ s0 100 $0683201300010000700016 \&$ Ing $=e n$

Perez, K.S., Ramos, M.L.G., McManus, C. 2004. Carbono da biomassa microbiana em solo cultivado com soja sob diferentes sistemas de manejo nos Cerrados. Pesquisa Agropecuária Brasileira 39 (6), 567-573. http://seer.sct.embrapa. br/index.php/pab/article/view/6809/3865

Pott, A., Pott, V.J. 2005. Alterações florísticas a planície do Baixo Taquari. In: Galdino, S., Vieira, L.M., Pellegrin, L.A. (ed.) Impactos ambientais e sócio-econômicos na Bacia do Rio Taquari Pantanal. Embrapa Pantanal. p. 261-293.

Silva, F.A.S.E., Azevedo, C.A.V. 2002. Versão do programa computacional Assistat para 0 sistema operacional Windows. Revista Brasileira de Produtos Agroindustriais 4, 71-78.

Sparling, G.P. 1992. Ratio of microbial biomass carbon to soil organic carbon as a sensitive indicator of changes in soil organic matter. Australian Journal Soil Research 30, 195-207. http://www.publish.csiro.au/paper/SR9920195. htm

Stieven, A.C., Campos, D.T.S., Malheiros, C.H., Silva, M.B.R.C., Ferreira, M.A.F., Oliveira, E.F., Elias
Neto, N. 2009. População e biomassa microbiana em três ecótipo na sub-região de Poconé, Pantanal de Mato Grosso. Revista Biodiversidade $1,10-26$.

TÓTOLA, M.R., CHAER, G.M. 2002. Microrganismos e processos microbiológicos como indicadores da qualidade dos solos. In: ALVAREZ V.,V.H.; SCHAEFER, C.E.G.R.; BARROS, N.F.; MELLO, J.W.V. \& COSTA, L.M., eds. Tópicos em ciência do solo. Viçosa, MG, Sociedade Brasileira de Ciência do Solo, v.2. p.195-276.

Wollum, A.G. Cultural methods for soil microorganisms. In: Page, A.L., Miller, R.H., Keeney, D.R. (Ed.). Methods of soil analysis. Soil Science Society of America, 1982. p.781-802. 